\title{
Chemical composition and antimicrobial properties of the essential oil from the leaves of Helichrysum ibityense R.Vig. \& Humbert (Asteraceae)
}

Zara Nomentsoa Razafiarimanga, Lovarintsoa Judicael, Randriamampianina, Hanitra Ranjana Randrianarivo, Saïd M’bae Sadam, Danielle Aurore Doll Rakoto and Victor Louis Jeannoda*

Laboratory of Applied Biochemistry to Medical Sciences, Fundamental and Applied Biochemistry Department, Faculty of Sciences, University of Antananarivo, P. O. Box 906, Antananarivo 101, Madagascar.

GSC Biological and Pharmaceutical Sciences, 2021, 15(03), 143-153

Publication history: Received on 05 May 2021; revised on 06 June 2021; accepted on 09 June 2021

Article DOI: https://doi.org/10.30574/gscbps.2021.15.3.0158

\begin{abstract}
The present work aimed to study the composition and antimicrobial properties of the essential oil of Helichrysum ibityense leaves (HIEO). HIEO was extracted by hydrodistillation from fresh leaves with a yield of $1.9 \%$. It had a relative density of 0.9247 at $20^{\circ} \mathrm{C}$, a refractive index of 1.4706 , an optical rotation of $-0^{\circ} 33$, an acid index of 2.10 and an ester index of 54. Gas chromatography analysis/flame ionisation detection of HIEO had identified 17 components, representing more than $99.54 \%$ of the overall composition of the HIEO including 1.8-cineole (69.46\%) the major component, $\alpha$-terpinene (4.62\%), $\beta$-caryophyllene (4.39\%), $\alpha$-pinene $(4.13 \%), \beta$-pinene $(2.96 \%), \mathrm{p}$-cymene $(2.39 \%)$ and $\gamma$-terpinene $(2.16 \%)$. The HIEO antimicrobial activity was tested against nine pathogenic bacteria including Staphylococcus aureus, Staphylococcus pneumoniae, Streptococcus pyogenes, Clostridium perfringens, Bacillus cereus, Pseudomonas aeruginosa, Enterobacter cloacae, Enterobacter aerogenes, Yersinia enterocolitica, and Candida albicans using the Disc diffusion and the Microdilution assays. HIEO exhibited broad activity spectrum and high microbial activity with inhibition zones (IZ) ranging from 12 to $35 \mathrm{~mm}$. On Bacillus cereus, the most sensitive bacterium, its Minimum Inhibitory Concentration (MIC) and Minimum Bactericidal Concentration (MBC) were $9.37 \mathrm{mg} / \mathrm{ml}$ and $13.22 \mathrm{mg} / \mathrm{ml}$ respectively. With an MBC/MIC ratio of 1.41, HIEO exerted a bactericidal action on Bacillus cereus. When administered orally to mice at $1000 \mathrm{mg} / \mathrm{kg}$ body weight, HIEO caused symptoms of intoxication which disappeared after $24 \mathrm{~h}$. These preliminary results revealed HIEO could be used to treat different infectious diseases if its safety will be confirmed.
\end{abstract}

Keywords: Helichrysum ibityense; Asteraceae; Essential oil; Chemical compounds; Antimicrobial properties; Toxicity

\section{Introduction}

The history of aromatic medicinal plants is associated with the evolution of civilizations. In all regions of the world, the history of peoples shows that these plants have always played an important role in the treatment of many diseases [1]. They are currently used in medicine, perfumery, cosmetics and culinary flavoring [2].

Essential oils are increasingly used in primary health care today. Studies have shown that aromatic plants are a reservoir of new remedies $[3,4]$. They are considered as sources of raw materials for the discovery of new molecules necessary for the development of future drugs [5].

Since the ban on antibiotics as a growth promoter in livestock farming in 2006, the search for alternatives such as plant extracts and in particular essential oils (EO) is undergoing significant development [6]. EOs applications are vast,

\footnotetext{
${ }^{*}$ Corresponding author: Victor Louis Jeannoda

Laboratory of Applied Biochemistry to Medical Sciences, Fundamental and Applied Biochemistry Department, Faculty of Sciences, University of Antananarivo, P. O. Box 906, Antananarivo 101, Madagascar. 
affecting well-being, health and the environment. The antimicrobial activity of plant extracts and EOs has been known for many years $[7,8,9]$. It is possible to sanitize the atmosphere with an essential oil ionizer. True aromatic aerosols are thus formed, ionized, creating ionic nascent oxygen, which is highly bactericidal, acaricidal and fungistatic, and without any toxicity for humans at the doses used $[10,11]$.

In Madagascar, where access to health care remains difficult for most of the population, traditional medicine is still widely used thanks to the therapeutic potentials of many plants. The diversity of aromatic plants endemic to Madagascar shows the real potential of its flora. Among them, the genus Helichrysum is well represented with its 115 endemic species. Traditional therapeutic uses of some Helichrysum species have been reported. For example, according to Benelli et al., [12], the juice from crushes Helichrysum faradifani leaves is used for healing wounds and as disinfectant for the treatment of opened boils and wounds and the leaf decoction is used in the treatment of syphilis, diarrhea, cough and headache. H. gymnocephalum is used to treat a variety of diseases, including stomach aches, headaches, typhoid, herpes, pyrosis, amenorrhea, dysmenorrhea, ulcers, goiter, rickets, gout, rheumatism etc. [13]. H. bracteiferum is considered as a stimulating plant and its ashes are used as a topical on excavated syphilitic wounds [13].

Some Malagasy Helichrysum species including $H$. faradifani $[12,14,15], H$. bracteiferum [16, 17], H. benthamii, H. dubardii, $H$. indutum, $H$. bojerianum, $H$. diotoides and $H$. hirtum [18], $H$. cordifolium, $H$. hypnoides, H. rusillonii [19], $H$. gymnocephalum and $H$. selaginifolium [17], $H$. aphelexioides, $H$. triplinerve, $H$. achyroclinoides, $H$. lecomtei, $H$. retrorsum [20] were already studied. However, works focused on the chemical composition of essential oils. Only a few species have been studied in terms of biological activity: H. gymnocephalum (Antiplasmodial and antioxydant activies, cytotoxicity) [21, 22], H. faradifani (Insecticidal activity) [12], H. bracteiferum and H. lavanduloides (Antibacterial activities) [22].

$H$. ibityense was chosen as the subject of this work mainly because no studies on it other than botanical ones have been reported so far. The fact that this plant has the same vernacular name ("Rambiazina") as H. gymnocephalum and H. bracteiferum, well-known for their therapeutic virtues in traditional Malagasy medicine, suggested that it may have the same therapeutic properties as these two medicinal plants. Indeed, the data we collected during our fieldwork on traditional therapeutic uses of $H$. ibityense were reminiscent of some of those known for H. gymnocephalum and H. bracteiferum especially their antibacterial properties. Thus, the main objectives of our investigations were to determine the chemical composition of the essential oil extracted from the fresh leaves of $H$. ibityense and evaluate its antimicrobial activities.

\section{Material and methods}

\subsection{Materials}

\subsubsection{Plant material}

The Helichrysum genus belongs to the Asteraceae family and has more than 400 species mostly found in Australia, southern Africa and Madagascar. Helichrysum ibityense is one of the hundred and fifteen (115) Helichrysum species endemic to Madagascar. This plant is a shrub from 1 to $4 \mathrm{~m}$ high (Figure 1) [23, 24].

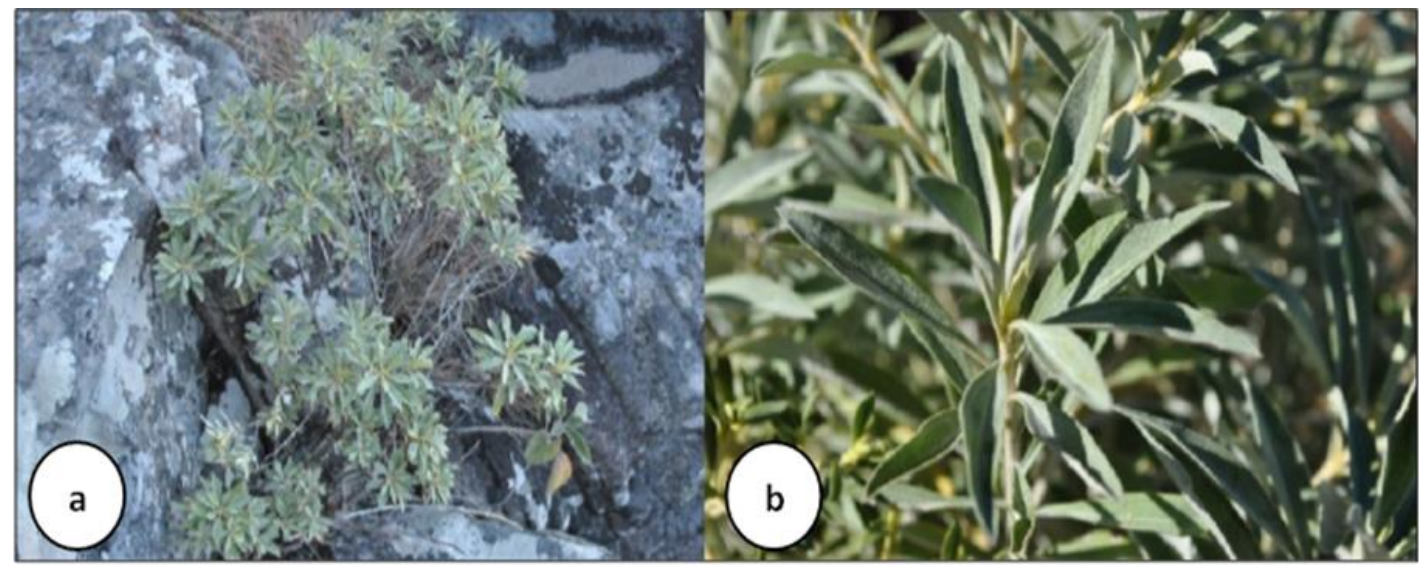

Figure 1 Helichrysum ibityense: a) the whole plant and b) leaves 
It grows abundantly in the highlands of Madagascar. It is found in the Andringitra forest, Marojejy forest corridor, South Anjanaharibe and North Tsaratanana, Manongarivo, Tsaratanana and in the Mount Ibity. The plant samples were collected in June 2020 on the Mount Ibity (2003' 56, 7' S, $047^{\circ} 00^{\prime} 02$, 2" E) in the Vakinankaratra region.

\subsubsection{Microbial strains}

The microbial strains used are pathogens commonly sought in medical and food microbiological analysis and/or control. They include Gram (-) and Gram (+) bacteria and a yeast (Table 1 ).

Table 1 List of microbial strains used

\begin{tabular}{|l|c|l|}
\hline Germ-Tests & Gram & Reference \\
\hline Staphylococcus aureus & + & ATCC 6538 \\
\hline Staphylococcus pneumoniae & + & ATCC 6505 \\
\hline Streptococcus pyogenes & + & ATCC 19615 \\
\hline Clostridium perfringens & + & ATCC 13124 \\
\hline Bacillus cereus & + & ATCC 14579 \\
\hline Pseudomonas aeruginosa & - & ATCC 10145 \\
\hline Enterobacter cloacae & - & ATCC 13047 \\
\hline Enterobacter aerogenes & - & ATCC 13048 \\
\hline Yersinia enterocolitica & - & ATCC 23715 \\
\hline Candida albicans & & ATCC 10321 \\
\hline
\end{tabular}

\subsubsection{Animals}

OF-1 strain Albino mice (Mus musculus), weighing $25 \pm 2$ g, were provided by the Pasteur Institute of Madagascar (IPM) breeding farm.

\subsection{Methods}

\subsubsection{Extraction of the essential oil of Helichrysum ibityense (HIEO)}

The extraction of the essential oil (EO) from the fresh leaves was carried out by hydrodistillation using a Clevenger type apparatus [25].

\subsubsection{Physico-chemical characterization of HIEO}

The concentration of the pure EO was calculated from its relative density. The physico-chemical parameters to be determined and the references used are presented in Table 2.

Table 2 Parameters to determine and the standards used

\begin{tabular}{|l|l|}
\hline Parameters & Standards used \\
\hline Relative density & AFNOR, NF-T 75-111 \\
\hline Refraction index & AFNOR, NF-T 75-112 \\
\hline Rotation power & AFNOR, NF-T 75-13 \\
\hline Acid index & AFNOR, NF-T 75-103 \\
\hline Ester index & AFNOR, NF-T75-104 \\
\hline
\end{tabular}

\subsubsection{Essential oil analysis}

The chemical composition of HIEO was determined by gas chromatography/flame ionization detection (CPG/FID) [26]. 
The oil was analysed using a SHIMADZU GC 14-A chromatograph equipped with a TRACSIL TR-WAX fused silica (polydimethylsiloxane) capillary column (30 $\mathrm{mm} \times 0.32 \mathrm{~mm} \times 0.25 \mu \mathrm{m})$ and a flame ionization detector. The sample volume of $25 \mu \mathrm{l}$ was diluted in $0.5 \mathrm{ml}$ of isooctane. The carrier gas used was nitrogen $\left(\mathrm{N}_{2}\right)$.

The peaks obtained were identified using AMDIS software Version 2.69 (Automated Mass Spectral Deconvolution and Identification System).

\subsubsection{Assessment of antimicrobial activity}

All the methods used for antimicrobial assay were detailed in our previous paper [27, 28].

Antimicrobial susceptibility testing

The sensitivity of microorganisms to the essential oil was determined by the agar diffusion method or aromatogram. Sterile paper disks (6 mm in diameter BioMérieux ®, REF 549916) were soaked with pure essential oil and placed on the surface of the inoculated Mueller-Hinton Agar (Scharlauß). The Petri dishes were incubated at $37^{\circ} \mathrm{C}$ for $24 \mathrm{~h}$ and the Inhibition Zones (IZ) were measured. The sensitivity to the essential oil was classified according to the IZ diameter as: not sensitive (-) for IZ $\leq 8 \mathrm{~mm}$; sensitive (+) for $9 \geq \mathrm{IZ} \leq 14 \mathrm{~mm}$; very sensitive (++) for $15 \geq \mathrm{IZ} \leq 19 \mathrm{~mm}$ and extremely sensitive $(+++)$ for $\mathrm{IZ} \geq 20 \mathrm{~mm}[29]$.

Antibiotic and antifungal used as references in this study were respectively Neomycin $30 \mu \mathrm{g} /$ disc and Miconazole 500 $\mu \mathrm{g} /$ disc.

MIC and MBC determination

Minimum Inhibitory Concentration (MIC) and Minimum Bactericidal Concentration (MBC) were determined by microdilution method [30]. The standards used to interpret MIC results were those of Dalmarco et al. [31]. The essential oil type of action is bactericidal when the ratio MBC/MIC is $\leq 4$ or bacteriostatic when MBC/MIC is $>4$ [32, 33, 34].

\subsubsection{Toxicity determination}

A volume of $0.3 \mathrm{~mL}$ of HIOE per $25 \pm 2 \mathrm{~g}$ of body weight was administered to mice by oral route by means of an intubation cannula with a curved distal. Two batches of 5 male mice were used. The mice were observed for $24 \mathrm{~h}$.

\section{Results}

\subsection{Extraction yield and physico-chemical parameters}

The extraction yield of HIEO was $1.9 \%$. The values of the physico-chemical parameters determined are presented in Table 4.

Table 4 Physico-chemical indexes of HIEO

\begin{tabular}{|c|c|c|c|c|}
\hline Relative density & Refractive index & Rotation power & Acid index & Ester index \\
\hline $0.9247 \pm 0.0001$ & $1.4706 \pm 0.0002$ & $-0^{\circ} .33 \pm 0.17$ & $2.10 \pm 0.14$ & $54 \pm 2.47$ \\
\hline
\end{tabular}

\subsection{Chemical composition}

GC-FID analysis of HIEO identified 17 constituents representing approximately $99.54 \%$ of the overall composition (Figure 2 and Table 5). 1.8-cineole (69.46\%) was the main constituent and the predominant components were $\alpha$ terpinene $(4.62 \%), \beta$-caryophyllene $(4.39 \%), \alpha$-pinene $(4.13 \%)$ and, $\beta$-pinene $(2.96 \%)$, p-cymene $(2.39 \%)$ and $\gamma$ terpinene $(2.16 \%)$. 


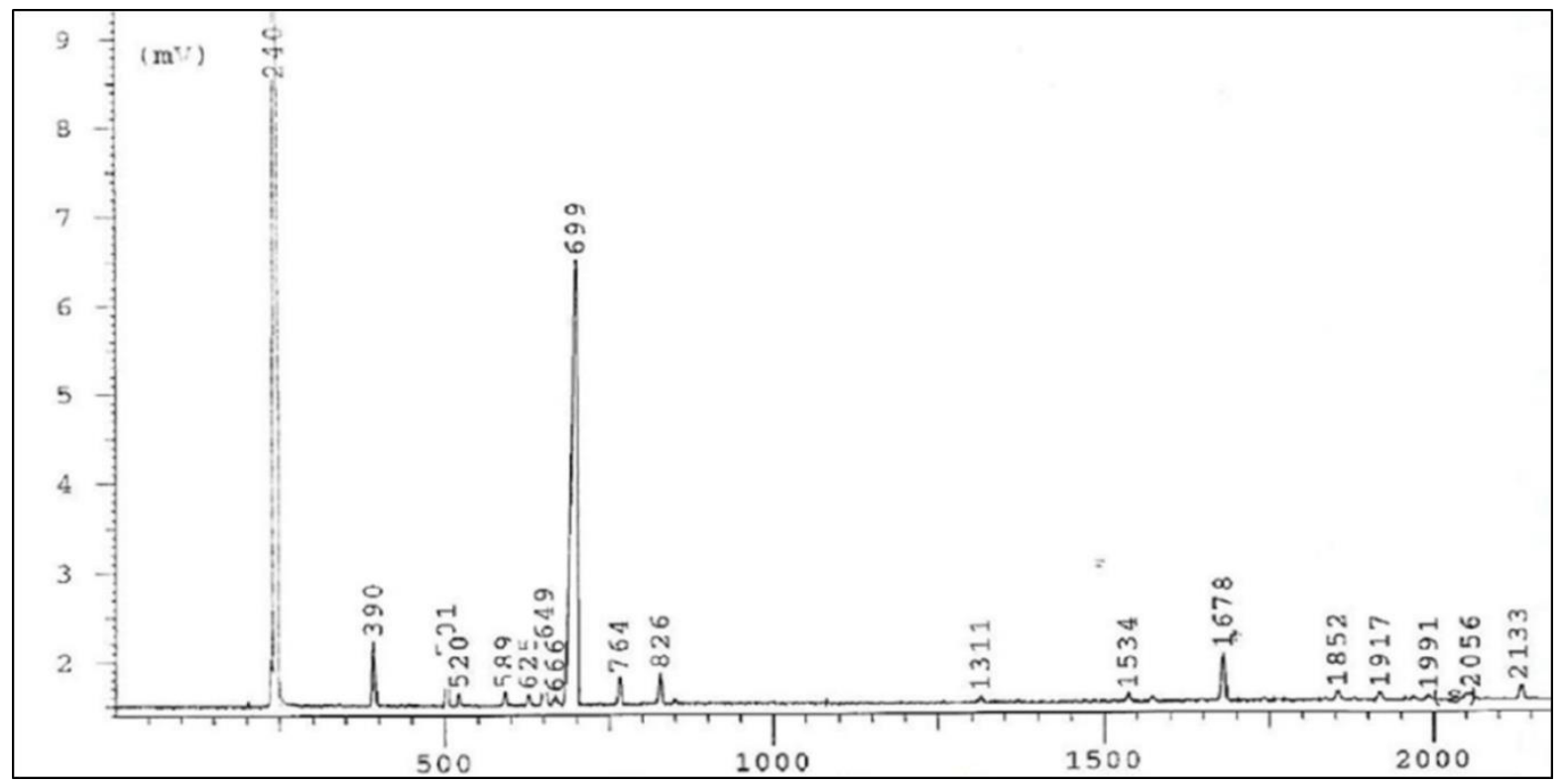

Figure 2 Chromatographic profile of HIEO

Table 5 Major components in HIEO

\begin{tabular}{|c|c|l|c|}
\hline Pic n $^{\circ}$ & Retention times & Components & Relative rates (\%) \\
\hline 1 & 390 & $\alpha$-pinene & 4.13 \\
\hline 2 & 501 & $\beta$-pinene & 2.96 \\
\hline 3 & 520 & sabinene & 0.90 \\
\hline 4 & 589 & $\beta$-myrcene & 1.09 \\
\hline 5 & 625 & $\alpha$-phellandrene & 0.91 \\
\hline 6 & 649 & $\alpha$-terpinene & 4.62 \\
\hline 7 & 666 & limonene & 0.92 \\
\hline 8 & 699 & 1 -8-cineole & 69.46 \\
\hline 9 & 764 & $\gamma$-terpinene & 2.16 \\
\hline 10 & 1311 & $p$-cymene & 2.39 \\
\hline 11 & 1534 & linalol & 0.68 \\
\hline 12 & 1678 & $\beta$-caryophyllene & 4.39 \\
\hline 13 & 1852 & aromadendrene & 1.01 \\
\hline 14 & 1917 & $\alpha$-humulene & 0.80 \\
\hline 15 & 1991 & $\alpha$-terpineol & 0.50 \\
\hline 16 & 2056 & $\beta$-selinene & 1.06 \\
\hline 17 & 2133 & $\gamma$-cardinene & 1.56 \\
\hline & & & \\
\hline
\end{tabular}

\subsection{Antibacterial activity of HIEO}

\subsubsection{Aromatogram}

The HIEO antimicrobial activity was tested at $923 \mathrm{mg} / \mathrm{ml}$ against nine strains of bacteria and one yeast using the disc method on solid medium. HIEO IZs on the germs tested are shown in Table 6. 
Table 6 Qualitative assessment of HIEO antibacterial efficacy by disc diffusion method

\begin{tabular}{|c|c|c|c|c|}
\hline \multirow[b]{2}{*}{ Strains } & \multicolumn{4}{|c|}{ Inhibition zone (mm) } \\
\hline & $\begin{array}{c}\text { IZ } \\
(9.23 \mathrm{mg} / \text { disk })\end{array}$ & Sensitivity & $\begin{array}{c}\text { Neomycin } \\
(30 \mu g / d i s k)\end{array}$ & $\begin{array}{c}\text { Miconazole } \\
\text { (500 } \mu \mathrm{g} / \mathrm{disk})\end{array}$ \\
\hline Staphylococcus aureus & 12 & + & 18 & \\
\hline Staphylococcus pneumoniae & 16 & ++ & 19 & \\
\hline Streptococcus pyogenes & 14 & + & 24 & \\
\hline Clostridium perfringens & 10 & + & 22 & \\
\hline Bacillus cereus & 35 & +++ & 21 & \\
\hline Pseudomonas aeruginosa & 12 & + & 18 & \\
\hline Enterobacter cloacae & 13 & + & 27 & \\
\hline Enterobacter aerogenes & 11 & + & 19 & \\
\hline Yersinia enterocolitica & 14 & + & 20 & \\
\hline Candida albicans & 20 & +++ & & 25 \\
\hline
\end{tabular}

According to the standard used by Ponce et al. [29]. HIEO was active on all (10) microbial strains tested with IZ ranging from $10 \mathrm{~mm}$ (Clostridium perfringens) to $35 \mathrm{~mm}$ (Bacillus cereus).

\subsubsection{HIEO MIC and MBC on Bacillus cereus}

The MIC and MBC of HIEO were determined on the most sensitive strain (Bacillus cereus) in the aromatogram. HIEO was tested at various concentrations $(7.21$ to $14.42 \mathrm{mg} / \mathrm{ml})$. The results are shown in Table 7.

Table 7 Determination of the HIEO MIC and MBC on Bacillus cereus

\begin{tabular}{|l|c|c|c|c|c|c|c|c|c|c|}
\hline Wells number & 1 & 2 & 3 & 4 & 5 & 6 & 7 & 8 & 9 & 10 \\
\hline Concentrations (mg/ml) & 14.42 & 13.22 & 12.14 & 11.13 & 10.21 & 9.37 & 8.59 & 7.89 & 7.23 & 7.21 \\
\hline Turbidity & - & - & - & - & - & - & + & + & + & + \\
\hline Results & & MBC &
\end{tabular}

(-): Clear medium; (+): Turbid medium

The HIEO MIC was $9.37 \mathrm{mg} / \mathrm{ml}$ and the MBC were $13.22 \mathrm{mg} / \mathrm{ml}$ (Table 6). The MBC/MIC ratio was less than 4 (1.41), which demonstrated that HIEO had a bactericidal action on Bacillus cereus.

\subsubsection{HIEO toxicity}

After orally administration of three doses of HIEO (100 mg/kg, $500 \mathrm{mg} / \mathrm{kg}$ and $1000 \mathrm{mg} / \mathrm{kg})$, some symptoms were observed including abdominal contortion, piloerection, weakening of the animal, convulsions and difficulty in moving. The mice recovered gradually and after 24 hours no mortality was observed.

\section{Discussion}

For the same plant, the chemical compounds present in an essential oil are not constant. They can vary greatly depending on the biotope (sunshine, climate, soil composition, altitude, etc.), the part of the plant (leaves, bark, flowers, fruit, etc.) and the harvesting period $[35,36]$ which can often correspond to specific vegetative stages of the plant. Therefore, their pharmacological properties could also vary greatly. 
In this study, the HIOE analysis was performed on leaves collected at the same location (Mount Ibity) in June when the plant was not bearing flowers or fruits. Therefore, as stated above, the chemical composition might be different if HIEO was extracted from plant material collected at other times.

The yields of essential oils are extremely variable depending on the plants considered, but they are generally very low, below 1\% [37]. That of HIEO is well over 1 (1.9\%) whereas that of several Malagasy Helichrysum EOs are below 1\%: $0.4 \%$ for $H$. gymnocephalum EO [16]; 0.01, 0.012, 0.03, 0.07, and 0.16 for H. selaginifolium, H. hypnoides, H. cordifolium, $H$. faradifani and H. bracteiferum respectively [17].

Seventeen (17) compounds were detected in HIOE. Compared to the number of compounds found in other Malagasy Helichrysum EOs, this value was relatively low: 23 for H. gymnocephalum [19]; 43 for H. bracteiferum [16]), 47 for H. faradifani [14]. However, as mentioned above, this number could change significantly at other times of the harvest.

The knowledge of physical and chemical indices is important because it allows the characterization and identification of an essential oil [38]. In addition, it makes it possible to decide their utilization in eating, pharmaceuticals and industrial making [39]).

The density of EO is very often lower than 1 (density of water) and varies according to their chemical composition: the value of 0.92 can be considered as an average. The HIEO density was 0.924 . The AFNOR standards (2005) recommends a density between 0.906 for low quality oils and 0.990 for very high-quality oils and set a density of 0.925 below which the oil is considered to be quality III [40].

Refractive index is a physical constant which is used frequently to test the purity of oils [39]). The lower the refractive index, the better the quality of the essential oil. According to the AFNOR 2005 standards, the refractive index of an essential oil should be between 1.495 and 1.513, 1.495 for high quality oils and 1.513 for lower quality oils [40]. With a refractive index of 1.470, HIEO can be considered to be of good quality in terms of purity. According to Kanko et al. [41], the low refractive index of essential oils (1.4710 to 1.4880) indicate their low refraction of light, which could favour their use in cosmetic products.

The rotation power rotation power of HIEO was - $0^{\circ} 33$. It was different from that of other Malagasy species which was - $7^{\circ} 50$ for H. gymnocephalum, $+9^{\circ} 10$ for H. lavanduloides and $+9^{\circ} 30$ for H. bracteiferum [16].

The acid index should be as small as possible and acid index of less than 2 is an indicator of a good conservation of the oil [40]. The HIEO acid index (2.10) was significantly lower than those of leaves EOs from Chromolaena odorata (15.62) and Pimenta racemosa (7.39) but higher than that of Cananga odorata EO (0.421) [40]. The low acidity of oils is considered as neutralized and safe for making skin care products whereas high acidity of oils may be harmful for skin. According to Kumar [39] with an acid value of 1.12 Kaempferia galanga oil has an exceptional shelf life and edibility.

The HIEO ester index (54) is significantly higher than that of Chromolaena odorata (21) and for Pimenta racemosa (33.75) [43], but by far inferior to that of Kaempferia galanga rhizomes EO (189.65) [39] and Cananga odorata flower EO (350.6) [40]. The higher the ester index, the better the quality of an EO [40].

As reported by Rabehaja et al. [18], Malagasy Helichrysum EOs exhibited an important chemical variability. The major components of EOs vary according to the species: for examples, $\alpha$-pinene for $H$. benthamii, caryophyllene for $H$. indutum and $H$. bojerianum [18] and 1.8-cineole for H. dubardii [18], H. gymnocephalum and H. bracteiferum [17].

There are large differences between the proportions of the major components in HIOE and those in other Malagasy species. As examples, 1.8 -cineole: $69.5 \%$ vs $7.1 \%$ for $H$. selaginifolium [17] and $0.7 \%$ for $H$. faradifani [15]; $\beta$ caryophyllene: $4.39 \%$ vs $46.4 \%$ for $H$. cordifolium [19]; $\beta$-pinene: $2.96 \%$ vs $38.2 \%$ for $H$. selaginifolium [17); limonene: $0.92 \%$ vs $5 \%$ for $H$. bracteiferum and p-cymene: $2.39 \%$ vs $4.3 \%$ for $H$. gymnocephalum and sabinene: $0.90 \%$ vs $9.8 \%$ for H. hypnoides.

The composition of HIEO was largely dominated by 1.8-cineole (69.46\%). High contents of this compound were also found in endemic species of Madagascar including H. bracteiferum EO (27.3\%) and H. gymnocephalum EO (59.7\%) [17]. In contrast, the European species H. stoechas and H. italicum EOs do not contain it $[44,45]$. Concerning the HIEO other major components, the $\beta$-pinene and $\beta$-caryophyllene contents were low (2.96\% and $4.39 \%$ respectively) compared to $\beta$-pinene (38.2\%) for the H. selaginifolium EO [19] and $\beta$-caryophyllene (46.4\%) for H. cordiofolium EO [17]. 
Antimicrobial activity of a given essential oil may depend on one or two of the major constituents only that make up the entire oil but the interactions between these and minor constituents in the oils are also important [46].

Like the EOs of other Malagasy species of Helichrysum, (H. lavanduloides, H. bracteiferum and H. gymnocephalum) [22], HIEO also exhibited antibacterial activities. It was active on all the tested microbial strains. Bacillus cereus and Candida albicans were extremely sensitive with IZ of $35 \mathrm{~mm}$ and $20 \mathrm{~mm}$ respectively. Investigations of the HIEO antimicrobial properties should be extended to other pathogens.

As mentioned above, 1.8-cineole was the main component of HIEO and given its various known pharmacological properties, it probably played a determining role in the antibacterial activity of HIEO. Indeed, this compound has antiviral properties (Anti-infectious bronchitis virus or anti-IVB) and is a potential source of anti-IVB ingredients for the pharmaceutical industry [47]. In Germany, 1.8-cineole is an authorized medicinal product, formulated in soluble capsules indicated for acute and chronic bronchitis, sinusitis and respiratory infections [48]. In Madagascar, the EOs of Ravintsara (Cinnamomum camphora) and Mandravasarotra (Cinnamosma fragrans), rich in 1.8-cineole (50\%), are used to treat different types of infections: viral and bacterial respiratory tract infections, urinary tract infections, gynaecological infections, oral infections, parasitic infections etc. The contribution of other components known for their antibacterial activities and present in HIEO such as $\beta$-carophyllene, $\beta$-pinene, p-cymene and limonene could not be excluded.

The antimicrobial activity of essential oils is due to their solubility in the phospholipid bilayer of cell membranes of bacteria and mitochondria, resulting in loss of membrane integrity and increased permeability. This could result in the death of bacterial cell due to leakage of critical molecules and ions from the bacterial cell to a great extent [46].

Since 1.8-cineole is present in large amount in HIEO and known to be toxic at high doses, a preliminary acute toxicity test was carried out on mice to assess the toxicity of HIEO. Indeed, 1.8-cineole is a powerful neurotoxicant: in humans, oral ingestion of doses from 10 to $30 \mathrm{ml}$ of essential oil with 70\% 1.8-cineole is potentially fatal [42]. In mice it has a relatively high oral $\mathrm{LD}_{50}$ of $3849 \mathrm{mg} / \mathrm{kg}$ (low toxicity), but at high doses it causes pathological changes in the liver and kidney after 30 days of treatment [49]. At $1000 \mathrm{mg} / \mathrm{kg}$ body weight, HIEO did not kill the mice but caused disturbing symptoms such as convulsions and movement difficulties which disappeared after 24 hours. Therefore, in depth toxicological investigations will be necessary to better understand the toxicity of HIEO and to determine the conditions of its possible safe uses.

\section{Conclusion}

The chemical composition and physicochemical characteristics of the essential oil of $H$. ibityense leaves are well established. The first data on its antibacterial activity have been acquired. Thanks to its rapid growth and the quality of its oil, $H$. ibityense constitutes a potential source of interesting and accessible therapeutic molecules. These results contribute to the knowledge of the endemic Helichrysum of Madagascar.

\section{Compliance with ethical standards}

\section{Acknowledgments}

We sincerely acknowledged the National Environmental Research Centre and the IPM for their helpful support to this work.

\section{Disclosure of conflict of interest}

The authors declare no conflict of interests.

\section{Statement of ethical approval}

All the tests on animals were approved and in line with the standard established by Ethics Committee of the IPM 


\section{References}

[1] Schauenberg P, Paris F. Guide des plantes médicinales: Analyse, description et utilisation de 400 plantes. Ed. Delachaux et Niestlé. 396.

[2] El Amri. Etude de l'activité antibactérienne des huiles essentielles de Teucrium capitatium L et l'extrait de Silene vulgaris sur différentes souches testées. Journal of Applied Biosciences. 2014; 82: 7481-7492.

[3] Zouhir A, Jridi T, Nefzi A., Hamida JB, Sebei K. Inhibition of methicillin-resistant Staphylococcus aureus (MRSA) by antimicrobial peptides (AMPs) and plant essential oils. Pharmaceutical Biology. 2016; 54(12): 3136-3150.

[4] Zahir I, Zahir A, Taghiam I. Effet antimycobactérien des plantes marocaines. Revue Générale. European Scientific Journal. 2018; 14(36): 518-548.

[5] Gazengel J-M, Orecchioni A-M. Le préparateur en pharmacie. 2ème édition. Ed. Lavoisier. Paris. 2018.

[6] Alleman F, Gabriel I, Dufourcq V, Perrin F, Gabarrou JF. Utilisation des huiles essentielles en alimentation des volailles. Performance de croissance et règlementation. Ecole d'Ingénieurs De Purpan. INRA Production Animale. 2013; 26(1): 3-12.

[7] Hammer KA, Carson CF, Riley TV. Antimicrobial activity of essential oils and other plant extracts. Journal of Applied Microbiology. 1999; 86: 985-90.

[8] Hammer KA, Carson CF, Riley TV. Melaleuca alternifolia (Tea Tree) oil: a review of antimicrobial and other medicinal properties. Clinical Microbioliology Reviews. 2006; 19(1): 50-62.

[9] Koch C, Reichling J, Schneele J, Schnitzler P. Inhibitory effect of essential oils against herpes simplex virus type 2. Phytomedicine. 2008; 15(1-2): 71-78.

[10] Mallea M, Soler M, Anfosso F, Charpin J. Activité antifongique d'essences aromatiques. Pathologie Biologie. 1979; 27: 597-602.

[11] Inyoue S, Goi H, Miyouchi K, Ogihara M, Iwanami I. Inhibitory effect of volatil components on the proliferation of bacteria. Bokin Bobai. 1983; 11: 609-615.

[12] Benelli G, Pavela R, Rakotosaona R, Randrianarivo E, Nicoletti M, Maggi F. Chemical composition and insecticidal activity of the essential oil from Helichrysum faradifani endemic to Madagascar. Natural Product Research. 2018; 32(14): 1690-1698.

[13] Samyn JM. Plantes utiles des hautes terres de Madagascar. Intercoopération, Organisation Suisse pour le développement et la cooperation. 1999; 81.

[14] Cavalli J-F, Tomi F, Bernardini A-F, Casanova J. Chemical variability of the essential oil of Helichrysum faradifani Sc. Ell. From Madagascar. Flavour and Fragrance Journal. 2006; 21: 111-114.

[15] Ralijerson LB, Rabehaja DJR, Rajaonarison JF, Ratsimamanga Urverg S, Hérent M-F, Mavar-Manga H, Tilquin B Comparison between the fresh and dry essential oil of Helichrysum faradifani Scott Elliot from Madagascar. Journal of Essential Oil Research. 2005; 17: 597-600.

[16] Ramanoelina PAR, Bianchini J-P and Gaydou EM. Chemical composition of essential oil of Helichrysum bracteiferum. Journal of Essential Oil Research. 1992; 4(5): 531-532.

[17] Cavalli JF, Ranarivelo L, Ratsimbason M, Bernardini A-F, Casanova J. Constituents of the essential oil of six Helichrysum species from Madagascar. Flavour and Fragrance Journal. 2001; 16: 253-256.

[18] Rabehaja DJR, Bezert G, Rakotonandrasana SR, Ramanoelina PAR, Andrianjara C, Bighelli A. Félix Tomi and Mathieu Paoli. Chemical composition of aerial parts essential oils from six endemic Malagasy Helichrysum species. Plants. 2020; 9: 265.

[19] Baser KHC, Demirci B, Kirimer N. Compositions of the essential oils of four Helichrysum species from Madagascar. Journal of Essential Oil Research. 2020; 14: 53-55. (January/February 2002).

[20] Randriaminahy M, Proksch P, Witte L, Wray V. Lipophilic phenolic constituents from Helichrysum species endemic to Madagascar. Zeitschrift für Naturforschung. 1992; 47c: 10-16.

[21] Afoulous S, Ferhout H, Raoelison EG, Valentin A, Moukarzel B, Couderc F, Bouajila J. Helichrysum gymnocephalum Essential Oil: Chemical composition and cytotoxic, Antimalarial and antioxidant activities, attribution of the activity, origin by correlations. Molecules. 2011; 16: 8273-8291. 
[22] Ramanoelina AR., Terrom GP, Bianchini JP, Coulanges P. Contribution à l'étude de l'action antibactérienne de quelques huiles essentielles extraites de plantes malgaches. Archive de l'Institut Pasteur de Madagascar. 1987; 53(1): 217 -226.

[23] Humbert H. Flore de Madagascar et des Comores. Tome II: 189ème Famille: Compositae. 1962; 440-450.

[24] Rasoanaivo P, Gorce PD. Essential oils of economic value in Madagascar: present state of knowledge. HerbalGram, 1998; 43: 31-39, 58-59.

[25] Clevenger JF. Apparatus for the determination of volatile oil. The Journal of the American Pharmaceutical Association. (1912) 1928; 17(4): 345-349.

[26] Arpino P, Prevot A, Tranchant J, Vergnol A, Witier P. Manuel pratique de chromatographie en phase gazeuse. Paris: Masson. 1995.

[27] Andriamampianina HL, Rakoto DAD, Petit T, Ramanankierana H, Randrianarivo HR, Jeannoda VL. Antimicrobial activity of extracts from Crotalaria bernieri Baill. (Fabaceae). African Journal of Microbiology Research. 2016; 10(3): 1229-1239.

[28] Randriamampianina LJ, Razafintsalama VE, Rakoto DAD, Randrianarivo HR, Jeannoda VL. Antimicrobial activity of seed extracts from Albizia bernieri E. Fourn. (Fabaceae). Journal of Pharmacy and Biological Sciences. $2017 ; 12$ (3): 72-79.

[29] Ponce AG, Fritz R, Del Valle C, Roura SI. Antimicrobial activity of essential oils on the native microflora of organic Swiss chard. Lebensmittel-Wissenschaft und-Technologie-LWT. 2003; 36: 679-684.

[30] Kuete V, Fozing DC, Kapche WFGD, Mbaveng AT, Kuiate JR, Ngadjui BT, Abega ZBM. Antimicrobial activity of the methanolic extract and compounds from Morus mesozygia stem bark, Journal ethnopharmacology. 2009; 124(3): 551-555.

[31] Dalmarco JB, Dalmarco EM, Koelzer J, Pizzolatti MG, Fröde TS. Isolation and identification of bioactive compounds responsible for the anti-bacterial efficacy of Lotus corniculatus var. São Gabriel. International Journal of Green Pharmacy. 2010; 4: 108-114.

[32] Djeussi DE, Noumedem JAK, Seukep J, Fankam AG, Voukeng IK, Tankeo SB, Nkuete AHL and Kuete V. Antibacterial activities of selected edible plants extracts against multidrug-resistant Gram (-) bacteria. Complementary and Alternative Medicine. 2013; 13(164): 1-8.

[33] Bouharb H, Badaoui KE, Zair T, Amri JE, Chakir S, Alaoui T. Sélection de quelques plantes médicinales du Zerhoun (Maroc central) pour l'activité antibactérienne contre Pseudomonas aeruginosa. Journal of Applied Biosciences. 2014; 78: 6685- 6693.

[34] Chamandi G, Olama Z, Holail H. Antimicrobial effect of Propolis from different geographic origins in Lebanon, International Journal of Current Microbiology and Applied Sciences. 2015; 4(4): 328-342.

[35] Jouault S. La qualité des huiles essentielles et son influence sur leur efficacité et sur leur toxicité. Diplôme d'Etat de Docteur en Pharmacie, Université de Lorraine. 2012; 144.

[36] Deschepper R. Variabilité de la composition des huiles essentielles et intérêt de la notion de chémotype en aromathérapie. Diplôme d'Etat de Docteur en Pharmacie, Université Aix-Marseille. 2017; 162.

[37] Laguerre V. Huiles essentielles et 1,8-cinéole. Sciences pharmaceutiques.hal-01770640. 2015.

[38] Lazouni HA, Benmansour A, Taleb-Bendiab SA, Sari DC. Composition des constituants des huiles essentielles et valeurs nutritives du Foeniculum vulgare Mill. Sciences \& Technologie C - N²5, Juin. 2007; 7-12.

[39] Kumar A. Physico-chemical and natural products investigations of essential oil from the rhizomes of Kaemp feria galanga L. Der Chemica Sinica. 2014; 5(2): 91-94.

[40] De Cliff S, Harerimana PC. Extraction de l'huile essentielle complète des fleurs de Cananga Odorata de la Plaine de l'Imbo: Vers la vulgarisation d'une nouvelle filière de plante industrielle au Burundi. Revue de l'Université du Burundi - Série Sciences Exactes N²8. 2013; 1-7.

[41] Kanko C, Sawaliho BE-H, Kone S, Koukoua G, N'Guessan YT. Etude des propriétés physico-chimiques des huiles essentielles de Lippia multiflora, Cymbopogon citratus, Cymbopogon nardus, Cymbopogon giganteus. Comptes Rendus Chimie. 2004; 7: 1039-1042.

[42] Kaloustian J, Hadji-Minaglou F. La connaissance des huiles essentielles : qualitologie et aromathérapie. Entre science et tradition pour une application médicale raisonnée. Paris: Springer-Verlag France. 2012; 210. 
[43] Noudogbessi J-P, Kossou D, Sohounhloué DCK. Composition chimique et propriétés physico-chimiques des huiles essentielles de Pimenta racemosa (Miller) et de Chromolaena odorata (L. Robinson) Acclimatées au Bénin. Journal de la Société Ouest-Africaine de Chimie. 2008; 026: 11-19.

[44] Roussis V, Tsoukatou M, Chinou IB, Harvala C. Composition and Antibacterial Activity of the Essential Oils of Two Helichrysum stoechas Varieties growing in the island of Crete. November. Journal of Essential Oil Research. 2002; 14(6): 459-461.

[45] Djihane B, Wafa N, Elkhamssa S, Pedro De HJ, Maria AE, Mihoub ZM. Chemical constituents of Helichrysum italicum (Roth) G. Don essential oil and their antimicrobial activity against Gram-positive and Gram-negative bacteria, filamentous fungi and Candida albicans. Saudi Pharmaceutical Journal. 2017; 25(5): 780-787.

[46] Chouhan S, Sharma K, Guleria S. Antimicrobial activity of some essential oils-present status and future perspectives. Medicines. 2017; 4: 58.

[47] Yang Z, Wu N, Fu Y, Yang G, Wang W, Zu Y, Efferth T. Anti-infectious bronchitis virus (IBV) activity of 1,8-cineole: effect on nucleocapsid (N) protein. Journal of Biomolecular Structure and Dynamics. Dec 2010; 28(3): 323-30.

[48] Colalto C. REVIEW Volatile molecules for COVID-19: A possible pharmacological strategy? Drug Development Research. 2020.

[49] Xu J, Hu ZQ, Wang C, Yin ZQ, Wei Q, Zhou LJ, Li L, Du YH, Jia RY, Li M, Fan QJ, Liang XX, He CL, Yin LZ. Acute and subacute toxicity study of 1.8-cineole in mice. International Journal of Clinical and Experimental Pathology. 2014; 7(4): 1495-150. 